\title{
The Effect of Sino-Indian War, 1962 on Ethnic Communities of Arunachal Pradesh
}

Sayeda Fauzia Farmin ${ }^{+*}$ and Dr Barnali Sarma*

\section{Abstract}

The study is an attempt to analyse the socio-economic consequences of Sino-Indian war of 1962 on the ethnic communities of North-East Frontier Agency (NEFA), the present state of Arunachal Pradesh, geospatially located in North-East India. A careful analysis of the pre-independent history of the region suggests that both Ahoms and British rulers followed a policy of non-interference in the region as it was predominantly a tribal area. After independence, the Indian Government also followed the policy of minimal governance. The vital issues of infrastructure were also not given much emphasis until the war of 1962. As the Government realised the strategic importance of the state, a significant change in government policy can be witnessed. Apart from initiating development in infrastructure of the state, efforts were also made to nationalise the frontier. The present research aims to document the socio-economic changes brought by the war, using a critical analysis of a wide range of sources.

Keywords: Ethnic Identity; NEFA; Sino-Indian War; Hegemony; Nationalisation; Arunachal Pradesh; India

\footnotetext{
+ PhD Scholar, Department of History, Gauhati University, Assam, India

${ }^{*}$ Corresponding Author, Email: sayedafauzia6@gmail.com

¥ Associate Professor, Department of History, Gauhati University, Assam, India, email: barnalisarma11@gauhati.ac.in (C) 2020 Farmin \& Sarma. This is an Open Access article distributed under the terms of the Creative Commons Attribution License (http://creativecommons.org/licenses/by/2.0), which permits unrestricted use, distribution, and reproduction in any medium, provided the original work is properly cited.
} 


\section{Introduction}

The central purpose of this study is to investigate the effect of the Sino-Indian War, 1962 on ethnic communities of Arunachal Pradesh. The present state of Arunachal Pradesh, (formerly known as North East Frontier Agency, abbreviated as NEFA) is located in North East India, which is popularly known as the land of the Rising Sun. The Sino-Indian war of 1962 constitutes an important event of Indian history with farreaching consequences. Like most wars of world history, the Sino-Indian war had its antecedent in border disputes. Aksai Chin, an area lying between the Chinese autonomous region of Xinjiang and Tibet was claimed by India as a part of Kashmir region, whereas China claimed it to be a part of Xinjiang (Kumar, 2013). China questioned the legitimacy of the McMahon Line $^{1}{ }^{1}$ which separates NEFA ${ }^{2}$ from China. Although the dispute over the McMahon line remained dormant, it gained intensification after the flight of the Tibetan leader Dalai Lama into India by crossing the frontier of Assam on 31 March 1959. A series of border skirmishes followed the incident.

The actual war began on 20 October 1962, which lasted for two months after the Chinese army defeated Indian forces. Even though the war lasted for barely two months, the consequences were tremendous in the political, economic, and diplomatic aspects. According to the 1965 report of the Indian Defence Ministry, 1383 Indian soldiers were killed, 1696 were missing in action, 3968 soldiers were captured, and 1047 were wounded. The Chinese casualties were less when compared to Indian counterparts with 722 deaths and 1696 wounded (Burkitt, Scobell \& Wortzel, 2003). A report released by the Indian Ministry of Defence had stated that there was no precise estimate of casualties. There was a lack of organisation during the induction of troops in NEFA. The process of withdrawal too lacked organisation. The mountain divisions broke up into small groups who went their own way. Moreover, due to the harsh terrain of the battlefield, many dead bodies were never recovered. Due to these factors, it would never be possible to precisely determine how many soldiers were killed due to enemy action or extreme cold climatic conditions of the state of Arunachal Pradesh (India, 2006). The study begins with a review of relevant literature on the subject of study. This will be followed by a discussion of the methodology employed for this study. Following this, it will critically discuss the pre-independence history of NEFA; development of infrastructure and nationalisation of the frontier.

\section{Review of Literature}

The Sino-Indian war of 1962 is a widely researched subject. From academicians to soldiers, experts from diverse fields have written their version of history about the war. Most of them stress on the background and events leading to the war. Mention may be made of Himalayan Blunder: The Curtain-Raiser to SinoIndian war, 1962 by Brigadier J. P. Dalvi (1969). The book reflects on the immediate background of the war as well as a Brigadier's experience in conducting affairs at the battlefield. The book has exposed the politicisation of Indian army which can be accounted for as a major reason for the failure of India. Apart from writing about the bravery of Indian soldiers, he has written in occasional instances about the porters, engineers, medical officers; whose contributions cannot be neglected. Another authoritative account of the war - India's China War by Neville Maxwell (1970). While discussing the background of the war, the author based his views upon the classified account of the Henderson Brooks-Bhagat report. Based on official sources, the book gives an in-depth analysis of the official affairs of both nations during the war. It is the first account that has discussed the forward policy of Indian Prime

\footnotetext{
${ }^{1}$ The McMahon Line is the demarcation line between Tibet and North- East region of India. It was proposed by the British delegate Henry McMahon at the 1914 Shimla Conference. The Shimla Conference itself is an intricate exercise in diplomacy, power politics and espionage (for details, please read, Maxwell, 1970).

2 The term NEFA will mostly be used as the region was known as NEFA in the period under discussion
} 
Minister Jawaharlal Nehru. Air Marshall Bharat Kumar, in the book Unknown and Unsung: Indian Air Force in Sino-Indian war of 1962 (2013) has reflected on the role of Indian Air Force in the war. There remained a perception that air force was not used during the war. On the contrary, the Indian Air Force (IAF) had been involved in the logistical build-up in Ladakh and NEFA right from the time the first of many posts was set up in 1950. If we consider the role of IAF in the war, the book has succeeded mainly in its reflection. Wing Commander M. Sadatulla's1962 War: Supplying from the Air(2013) is another account that has dealt with the contribution of Indian Air Force towards war efforts. Shiv Kunal Verma's1962: The War That Wasn't (2016) is another detailed account of the war. The book is a definitive account of the conflict, based on dozens of interviews with soldiers, officers, support staff, bureaucrats, and numerous others who had a first-hand view of what actually happened in 1962. As the author is from a nonmilitary background, the book is free from biases that a soldier might commit to conceal the faults on military lines. Mention can also be made of Bharat Rakshak, a website devoted to discussing India's military affairs (India, 2006). It was started in 1997 by bringing together individual websites of Indian defence enthusiasts. In 2006, the site leaked Official war histories written by Indian Ministry of Defence that had remained classified for some time. The official war history of 1962 Sino-India war can be included in the literature regarding the event. The work contains ten chapters which discuss the circumstances and course of war from a military perspective. The work is relevant for understanding the official point of view regarding the war.

China's India War: Collision Course on the Roof of the World authored by Bertil Lintner (2018) has questioned Neville Maxwell's narrative. Lintner(2018) (insert year of publication) argues that China began planning the war as early as 1959 and thus, the forward policy of Nehru cannot be accused as the main reason for SinoIndian war of 1962. Shadow States - India, China and the Himalayas, 1910-1962 by BéréniceGuyot-Réchard (2017) is an important work on the topic. Here, the Sino Indian tension has been looked into from the perspective of competitive state-building. It involves a study of the simultaneous approach to achieve the support and acceptance of the people. In the 20th Century, there loomed considerably the tension between China and India for acquiring political hegemony in the Himalayan region. Their lack of strong ties to the region and the absence of an easily enforceable border made their proximity threatening. Observing China and India's state-making efforts, the local inhabitants were in a position to compare and potentially choose between them. Amid their state making efforts and the existence of an uncordial relation between the two entities, the local people had no other option but to choose their position between one of the two belligerents. The book provides an in-depth understanding of the genesis in the Indo China conflict.

Apart from Berenice Guyot Rechard's (2017) work, the existing literature has mostly stressed on the causes and consequences of the war. The war had many socio-economic impacts that had not gained due attention in the existing literature. The region of NEFA was particularly affected. After the war, the Central Government had made a significant shift in the policies adopted towards the tribes inhabiting the frontier regions of North-East India. As the Government realised the strategic importance of NEFA, particular emphasis was laid on the development of infrastructure in the hitherto neglected region. Apart from developmental efforts, measures were taken towards nationalisation of the frontier.

From the above discussion on the existing literature related to the war, it can be witnessed that the political outcome of the war is overemphasised, neglecting the socio-economic consequences of the event. The objective of the study is, therefore, to fill the gap in the existing literature by analysing the socio-economic changes brought by the war in the subsequent decades. As stated above, the study will also look into the nationalisation efforts initiated by the Central Government and the responses of the 
tribal communities of NEFA to those policies. The methodology is discussed in the next section.

\section{Methodology}

The present study follows historical methodology based on critical use of a range of primary and secondary sources, such as books, newspapers, government documents, documentary etc. To establish authenticity, gathered sources are evaluated, corroborated and then reproduced after careful and critical analysis. The following section discusses the preindependence history of NEFA.

\section{Pre-Independence History of NEFA}

Arunachal Pradesh is the largest state of NorthEast region of India and has one-eighth landmass of our country. It covers an area of 83743 sq.Kms (32333 square miles) and a long international border with Bhutan in the West $(160 \mathrm{Kms} ; 99$ miles), China in the north and north-east $(1,080$ Kms; 671 miles), and Myanmar in the east (440 Kms; 273 miles). It expands from the snowcovered mountains in the north to the Brahmaputra plains in the south (Singh, 2011). The mountain ranges of NEFA cover about 85 per cent of the total area of the state. The configuration of the land surface is extremely varied with an elevation of about 175 metres in the south to more than 5000 metres in the north. From the Brahmaputra valley in the south, the land gradually rises towards the north and finally penetrates the high mountain ranges of Eastern Himalayas. In general, the whole of NEFA is highly desiccated and has a rugged topography with very limited level land (Pande, 1997).

The pre-modern history of the region is shrouded amid traditions and mythology. Early reference of it can be traced in the epic stories of Mahabharata . In fact, the local traditions tend to identify the region around Sadiya as the ancient Vidarbha (Hussain, 1998:9). The archaeological remains at Malinithan too speaks

\footnotetext{
3 The posa system was introduced by the Ahom government to put a stop to the inroads of the hill people to the bordering territories. The Ahom government gave fertile lands to the hill people at the foot of their hills called 'khats' along with access to certain fisheries in the plains. In lieu of fertile lands, the Ahom government also paid a stipulated amount called posa consisting of such articles as
}

of Hindu contacts in the place. The remnants date back to the 13th -14th Century, historically suggesting to have been constructed by the Chutiya kings (Sharma, 1988). Another heritage site is the Tawang Monastery which speaks of local connections with Buddhism. It was for the geographical proximity with Tibet that the Tibetan culture found a space in the hearts and mind of the people in the region. However, recorded history of the place is available only in the Ahom chronicles from the 17th Century.

Hilly terrain with occasional valleys, the area is inhabited by around twenty-six major tribes, living in secluded and isolated grooves. The inhospitable terrain of mountain ridges, gushing rivers dense forests restricts the easy movement of people. The political relationship between the hills and the plains has always been a unique one. During the Ahom rule (1228-1826), the hill tribes of the neighbouring regions were allowed certain rights and privileges in the foot-hill lands of the plains, including the right of posa, ${ }^{3}$ that is, the main objective of this system was to defend the peasants cultivating in the foothills, whose products were often plundered by the hill tribes. Due to the rugged terrain of the hills, all products of necessity could not be produced by hillpeople. Therefore, they resorted to plundering and other unfair means to collect their necessities. The posa system introduced by the Ahoms put an end to hostilities between the hill tribes and plains people (Barpujari, 2007). In general, the Ahom kings adopted a policy of conciliation towards the tribes, supporting it by a display of force when it could be effectively employed. When the British took over the control of Assam, they largely followed the policy of the Ahom kings. They protected the plains people against their raids, established outposts in the foothills and from time to time imposed a blockade and undertook punitive

rice, cloth, cattle etc to be collected from a class of people called paiks assigned to them. The Ahoms organised the society on the basis of paik or khel system, which was the backbone of the socio-political organisation of medieval Assam. It was a system of exacting personal service from the subjects by the Ahom rulers (for details, please read, Baruah, 1985). 
expeditions against the frontier tribes (Hussain, 1998).

In 1874, the Britishers passed the Scheduled District Act ${ }^{4}$ to enforce a uniform administrative setup. In 1914, the Government of India issued a notification to apply Assam Frontier Tracts Regulation of 1880 to the areas of Adis, Mishimis, Nagas etc. and these hilly areas were separated from Darrang and Lakhimpur district of Assam and constituted into the North- East Frontier Tract (NEFT). In 1919, some changes were made and in 1935, these areas were converted into excluded areas under the control of the Governor of Assam. Thus, there has been a gradual political evolution. Between 1935 and 1943 this excluded area was placed directly under the control of the Governor of Assam, who ruled it in his discretion through an advisor. After independence, the responsibility to administer the Frontier Tracts was handed over to the Government of Assam. On 26 January 1950 the Constitution of India was proclaimed and along with it, a further change in administration was affected. NEFT was scheduled as part of Assam, but its administration was handed over to the Governor of Assam, who will act as an agent of the President of India. The next significant development was introduced in 1954 with the introduction of the North East Frontier Area (Administration) Regulation. The regulation formed NEFA, and fresh reorganisation of the existing administrative units was conducted, and consequently, some areas of Abor Hills district and Mishmi Hills district were transferred to the plains and the remaining hill areas were comprised in the hilly region of NEFA. The number of administrative divisions was raised to five from two divisions. Each division was placed under the charge of a Deputy Commissioner (Singh, 2011).

\footnotetext{
${ }^{4}$ The Scheduled District Act xiv of 1874 is an act of British Indian Government by which certain territories annexed by the British government were constituted as scheduled tracts. By the provisions of this act, extensive powers were vested in the local government (for details, refer to Bhattacharjya, 1991)

${ }^{5} \mathrm{Kebang}$ is traditional village council of the Adis. The prime responsibility of the village councils is to enforce law and
}

As already stated, the British maintained close control over the frontier tracts, treating them as excluded areas and sending out expeditionary missions as and when occasions demanded. After independence, the Government of India was also in favour of gradual political evolution. Prime Minister Nehru enunciated five principles of tribal administration, which later became famous as Panchasheel principles on tribal issues. He expressed them in the foreword that he wrote for Verrier Elwin (1959)'s book Philosophy for NEFA. The five principles may be summarised as:

- The indigenous people should be left to pursue their lives based on their own cultural practices and traditional art.

- Tribal rights in land and forests should be respected.

- A team of their own people ought to be developed - trained with the intricacies of modern administration, development strategies and technical know-how. But intrusion of too many outsiders should be avoided wherever possible.

- The stringent administrative procedure, complicated schemes should be avoided, rather development should be worked upon in coordination with the traditional social and cultural institutions.

- Results should be computed based on qualitative development rather than on the statistics of money expended in the region. It should be an attempt to win peoples' heart(Elwin, 1959: xi)

To execute his principles into practice, tribal institutions of village councils like the Kebang ${ }^{5}$ of the Adis and Buliang ${ }^{6}$ of the Apatanis were reactivated. A host of tribal interpreters was employed to serve as intermediaries between the administration and the local people. In 1956, a cadre of Indian Frontier Administrative Service

order in the society. There are other village councils of other tribes, such as, Buliang, Nyele etc. kebang is considered to be the most democratic village council of the tribes inhabiting Arunachal Pradesh.

${ }^{6}$ Buliang is the traditional village council of the Apatanis. The responsibility of the tribal village councils is to enforce law and order in the society. 
(IFAS) was created to give impetus to developmental activities. A relatively large number of qualified tribal officers from other tribal areas of Assam were employed for absorption in the Frontier service. As a result, an excellent right proportion of middle-rung officers were tribespeople themselves. These frontier officers were pioneers and worked with great zeal and zest as harbingers of development. To carry out their mission, they trekked thousands of miles on foot and faced immense hurdles (Singh, 2011).

The developments immediately following the war of 1962 are of particular importance which will be discussed later. It is to be mentioned that NEFA was constitutionally a part of Assam state until 1972. On 21 January, NEFA was designated as a Union territory of India and renamed Arunachal Pradesh. Another significant development came in the year 1987 when Arunachal Pradesh achieved statehood on 20 February (Cultural Roots of Arunachal Pradesh, 2019; Hussain, 1998:2). Development of infrastructure is discussed in the next section.

\section{Development of Infrastructure}

When the British left in August 1947, there was no 'core service' worth the name in the interior of the frontier tracts. They did not bother to create a nexus of social - welfare and technical services in the Hills. Communication, medical service, educational facilities were as good as non-existent. All that existed by way of communication was $168 \mathrm{~km}$ of roads in the plains areas, mostly along the foothills; there were 13 hospital and dispensaries and one leper colony - all located on the fringe of the hills; educational facilities consisted of two lower primary schools also located at the foot of the hills. So when the Government of India decided to carry the benefits of modern administration and social services to the people in the hills, it was obliged to build from scratch (Chowdhury, 1996).

During the year 1948-49, that is, after independence, a total expenditure of INR 700,000 was incurred for the whole area. It went up to INR 1,200,000 in 1950-51. During all these years, government spending accounted primarily for the spread of administration into the interior of the hills and building up communication lines, even though rudimentary. The full-scale development scheme was put into operation in 1953 after definite allotments on different heads of expenditure in the First Five Year plan (1950-55). A sum of INR 13,500,000 was allotted in the First Five Year Plan for the development of communication. From the mid1950s, when border skirmishes were going on, the Central Government paid particular attention to the development of roads and communication in the area. Both the Central and State Governments realised the importance of road connectivity and efforts were initiated to improve and strengthen the transport infrastructure in the state. In the Second FiveYear plan (1956-61), INR 50,956,000 was allocated in the sphere of communication. Out of the total plan outlay, road construction alone appropriated INR 15,400,000, and INR $2,560,000$ was allotted separately for the building of airstrips (Chowdhury 1996: 251). At the end of the period, roads were pushed through to all the five divisional headquarters, and 13 airstrips of various sizes were constructed. The task of major road-building projects was transferred from the Central Public Works Department (CPWD) to the Border Roads Organisation, which popularly came to be known as 'Tusker' (Chowdhury 1996:251). For the provision and maintenance of vital strategic communication in the belligerent terrain of the border, the Border Roads Organisation (BRO) was set up on 7 May 1960 (Dalvi, 1969). BRO raised project Vartak with the aim of efficient management of the Indo-China border. The organisation commenced survey operations in 1960. The workers of BRO had to work under immense difficulties due to lack of resources allotted to them and frequent landslides in the Southern slides of the Himalayas.

The major problem of building roads in the sector was the lack of stones to lay a metal foundation for the roads at convenient distances. Despite that, by 1962 a fair-weather one-ton road in Dirang valley was opened for vehicular traffic in the dry months. The road from Dirang to Tawang via Sela was barely fit for 
vehicles. There were numerous landslides and slushy patches where the hills were cut to widen the track. Sela was hugely snow-fed, and the engineers of BRO working at the height of over 1300 feet could not clear the track there despite of immense effort due to lack of modern equipment. Therefore, motor transport could not ply across the region. As such, there were no

\section{Table 1: Five-Year Plans and Expenditure on NEFA}

\section{Year}

First Five Year Plan(1950-55)

Second Five Year Plan(1956-61)

Third Five Year Plan(1962-66)

Source: Chowdhury 1996: 251 proper means of carrying loads in the mountains. Indian soldiers, not acclimatised to the hilly areas had to solely depend on the Animal Transport Company where local people were recruited (Dalvi, 1969:127). Lack of road infrastructure was one of the crucial causes of the failure of the Indian army in the 1962 war.
India's failure in the 1962 war influenced the shaping of the Third Five Year Plan (1962-66). The total outlay for NEFA in the Third Five-Year Plan was further enhanced, raising it to INR $71,500,000$ (Table 1). Besides normal allocation for communication, an extra allotment of INR $20,800,000$ was provided in the plan for improvement of communication (Chowdhury, 1996:253).

Earlier, because of the increasing strategic importance of the border roads, a Border Road Development Board had come up in New Delhi, and the Tusker in NEFA was made subordinate to it. Tusker came under severe criticism previously for slow progress in the execution of construction works. However, as already mentioned, the staff of Tusker had to work under severe circumstances due to landslides. Lack of modern equipment posed another problem. Nevertheless, unsatisfactory performance of the Tusker prompted the Government to entrust the construction and improvement of certain strategic highways to Army Engineer Corps in 1963. The targets set for the Third Five Year Plan concerning communication were 419 miles $(672 \mathrm{~km})$ of jeepable roads, 153 miles $(246 \mathrm{~km})$ of mule track, 841 miles $(1353 \mathrm{~km})$ of porter tracks besides improvement of existing roads. Construction of seven new airstrips and improvement of existing 13 airstrips were undertaken and completed in record time during the Third Five Year Plan period. The performance at the end of the plan period registered a higher mark (Chowdhury 1996:253)

Being a sparsely populated hilly terrain, NEFA had a self-sufficient economy. The unfavourable ecological environment sets certain outer limits beyond which human habitation and economic substances can rarely be possible. The areas beyond the altitudinal zone of $3000 \mathrm{~m}$ make such limits. Besides, the distribution of the population is also influenced by the prevailing socioeconomic setup of the state. The practices of shifting cultivation, communitarian ownership of land and clan territorial organisation of the social structure of the tribal groups have a bearing on the sparsely and uneven distribution of population in the state (Sharma 2008:15) Prior to the war, the modern way of the economy still had not arrived in the remote areas. Despite the harshness of nature, they had terraced fields and grew a variety of cereals, vegetables and fruits. Barter economy prevailed there. During the war, the army recruited them as civil porters. Brigadier J. P. Dalvi (Commander of 7th Indian Infantry Brigade) has mentioned about an interesting incident about ethnic porters of Tawang. When the porters were paid in cash, they hardly knew what to do with the coins earned. Dalvi has written how the arrival of the army brought a significant change in their economic life. As Dalvi (1969: 128) state:

The advent of the Army, Border Roads and the Civil Administration had upset their traditional life, and suddenly they 
found themselves earning and spending large sums of money, in place of the traditional barter system...at first, they did not know what to do with this strange means of payment for labour, services and goods, and just stuffed their notes in bamboo containers. Later, when the Administration opened stores, they shopped enthusiastically for the things that we are pleased to call the blessings of science and civilization... Bhutanese traders soon learnt to cater to their tastes and reaped a rich harvest at the monthly bazaar in Tawang. (Dalvi, 1969:128).

Thus, the arrival of the army also brought money economy to the region of Tawang. Earlier, the barter economy prevailed in the region. Gradually, with the expansion of the market, the ethnic porters learnt to cater to their needs in exchange for money.

The medical facility was also non-existent in the region. The extension of medical services got into stride in 1951 with the establishment of a separate Medical Department (Chowdhury 1996:252). At the end of the First FiveYear Plan, there were 19 hospitals, 22 indoor dispensaries, 17 outdoor dispensaries, 20 mobile health units, three leper colonies and 27 anti-malaria units. By the end of the Second Five Year Plan, eight base hospitals, located at divisional and sub-divisional headquarters, one central laboratory, one training-cum-research centre, a central tuberculosis hospital and 85 health units were added to the list (Chowdhury 1996:252). With the mobility of troops, modern medical facilities were introduced in the region. In 1960, when war preparations were going on, a Mobile Surgical Unit and a field ambulance were set up in Tawang. Within a week of their arrival Major Jayaraman, the Officer Commanding, performed a life-saving abdominal surgery using petromax lamps and hurricane lights. Thereafter, everything possible was done to house and look after this unit. By 1961, a 25-bedded hospital was established in Tawang (Dalvi, 1969:114). Gradually a concrete floor was provided and annexes built to protect medical stores and provide recreational centres. An X-ray plant was installed later. The plant was carried through Sela pass by 16 porters. The medical unit became extremely popular among the civilians and the locals, who previously never enjoyed the blessings of modern medicine and surgery (Dalvi 1969:114). The nationalisation of the frontier is being discussed in the next section.

\section{Nationalisation of the Frontier}

Apart from the developments in infrastructure and medical services, the Sino-Indian war of 1962 was a landmark in initiating nationalisation of the frontiers. Efforts were made to integrate NEFA emotionally with mainland India. As it is already mentioned, the region has a unique topography with distinct culture. In this context, two incidents are discussed below:

- Kapo is a remote village in Siang division of NEFA. By the middle of November 1962, Indian soldiers had withdrawn from that region due to impending defeat. In the absence of soldiers, the villagers of Kapo took it upon themselves to defend their village. Seeing the Chinese approaching Kapo, the residents cut off the hanging bridge on the way. The Chinese forces attempted thrice but were resisted.

At last, the Chinese overpowered the local people and occupied the village and started to live there from 22 to 24 November 1962. During their stay, they told the villagers to break away from the Nehru government. They harvested paddy from the fields of the fleeing people and kept them in their granary. Such benevolent actions were aimed at winning over the hearts of the simple tribe. However, the ethnic population of Kapo took cognisance of the event as a clear case of invasion (Hindustan Standard, 1963).

- Yaaku Tacho is a woman from Dibang valley who worked as a spy for the Chinese Government (The first I author interviewed the daughter of Yaaku Tacho, where Tacho's diary in Chinese language was also produced). She and 
her husband went to China with a small group of people from Dibang Valley. Most of the Mishmi people who went to China received education for eight to nine years. They viewed theChinese as very kind and believed that communists are friendlypeople. They spoke ofthe Chinese army as being good. Yaaku's daughter remembered what her parents told her about the time they reached China:

When we reached, we were welcomed. It was very nice. We were taught patriotism for China. We were told that China is the best. Boys and girls were kept in separate hostels. We were kept in a military school. We were always trained by military officers and we received weapons training."(Aiyadurai\& Lee, 2017:378)

Yaaku's diary also reflects that the Chinese accorded a cordial treatment to the Mishmis. They, therefore, were very much influenced by the Chinese propaganda stating India as their enemy and China their friend. Along with conventional education, the Mishmis were also provided training on the use of weapons. Eventually, some of the Mishmis even participated in the 1962 Sino-Indian war and fought against India. (Aiyadurai\& Lee, 2017:379)

These two narratives speak clearly of the existence of ambiguity in the borderlands where the common people were almost isolated from the mainstream. In the years following independence and the creation of nation-states, people like Yaaku Tacho and others went to China at this point of time "for all practical purposes, assuming both Indian and Chinese nationality (Baruah, 2003:936). But ambiguous identity and geographic spaces pose a threat to the nation's security and so nationalising such spaces had become urgent and crucial for the Government.

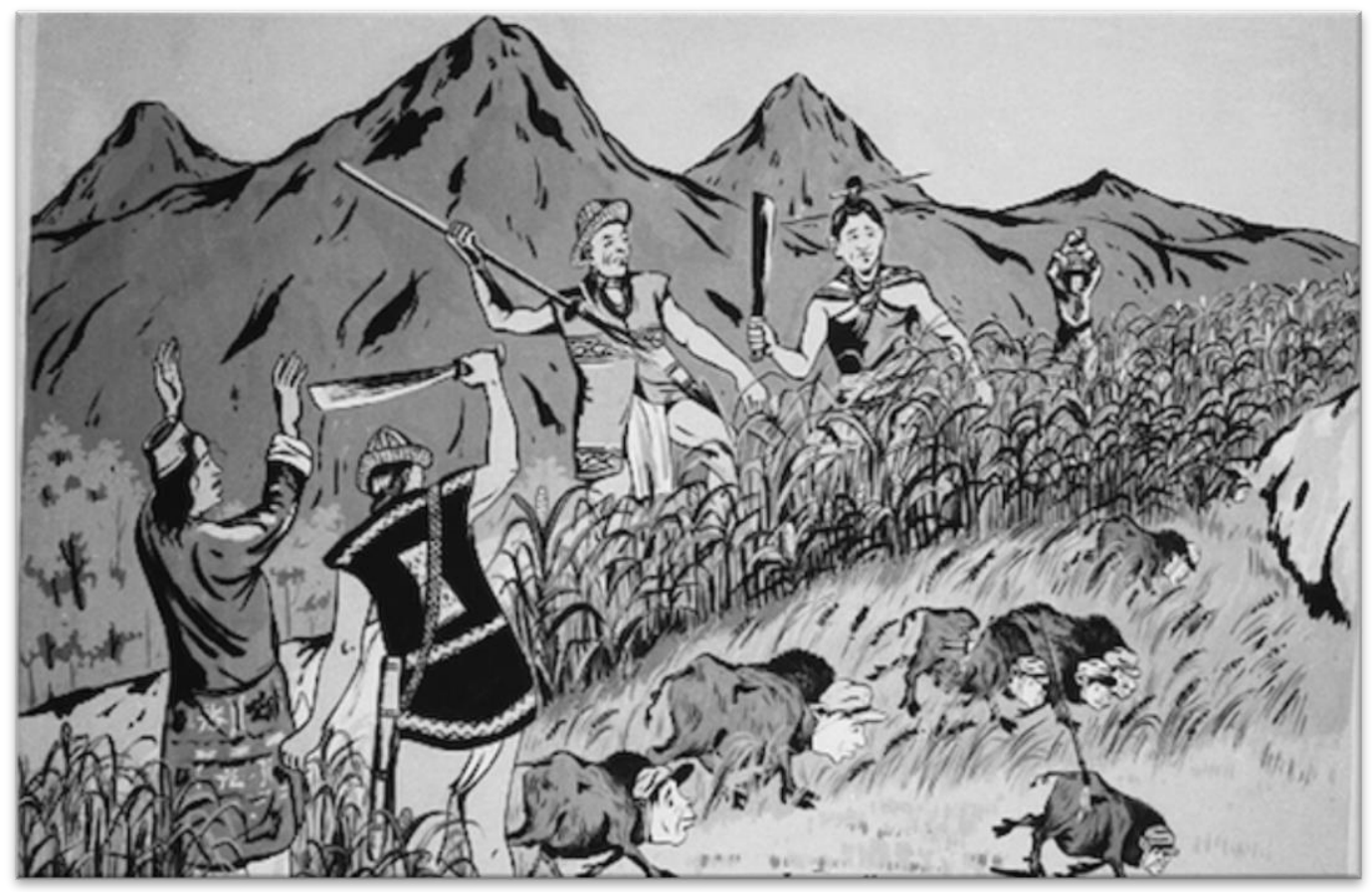

Figure 1

Source: Rechard, 2018 


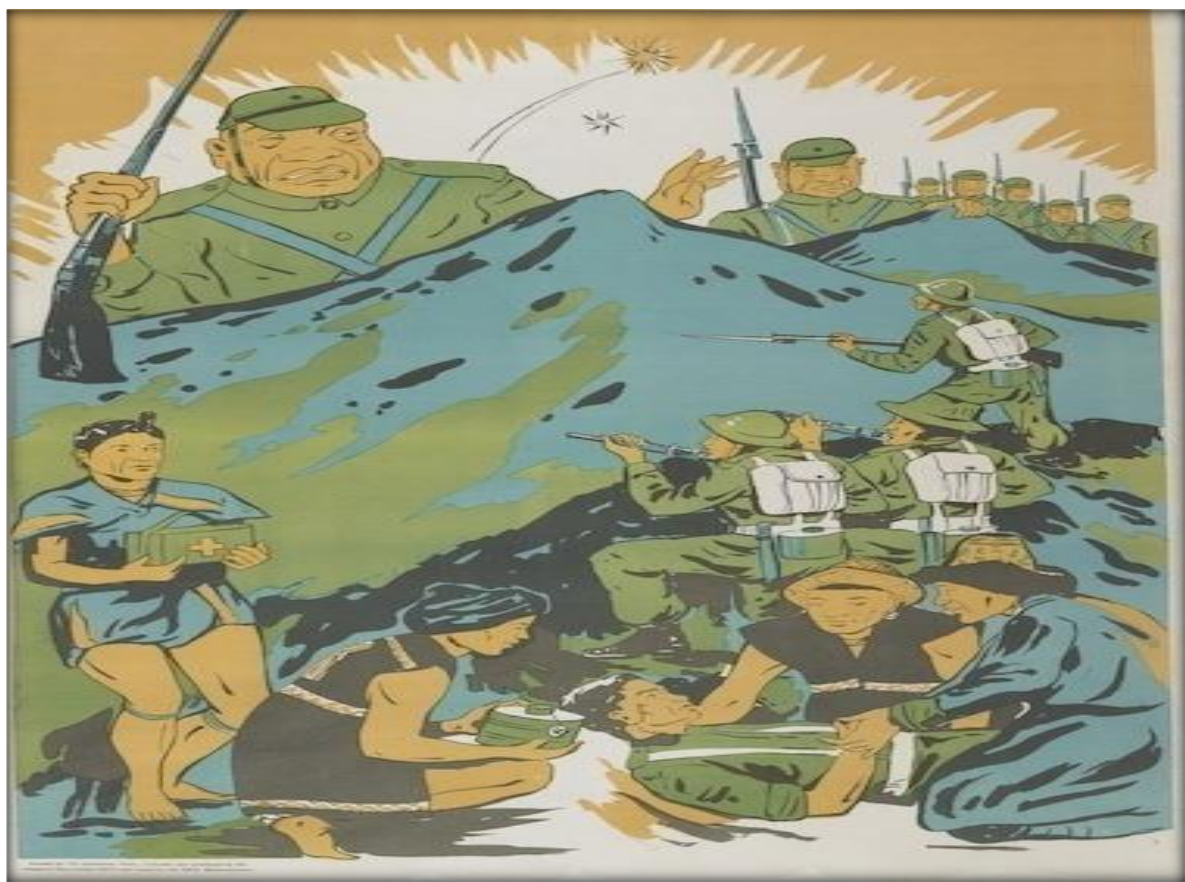

Figure 2

Source: Rechard, 2018

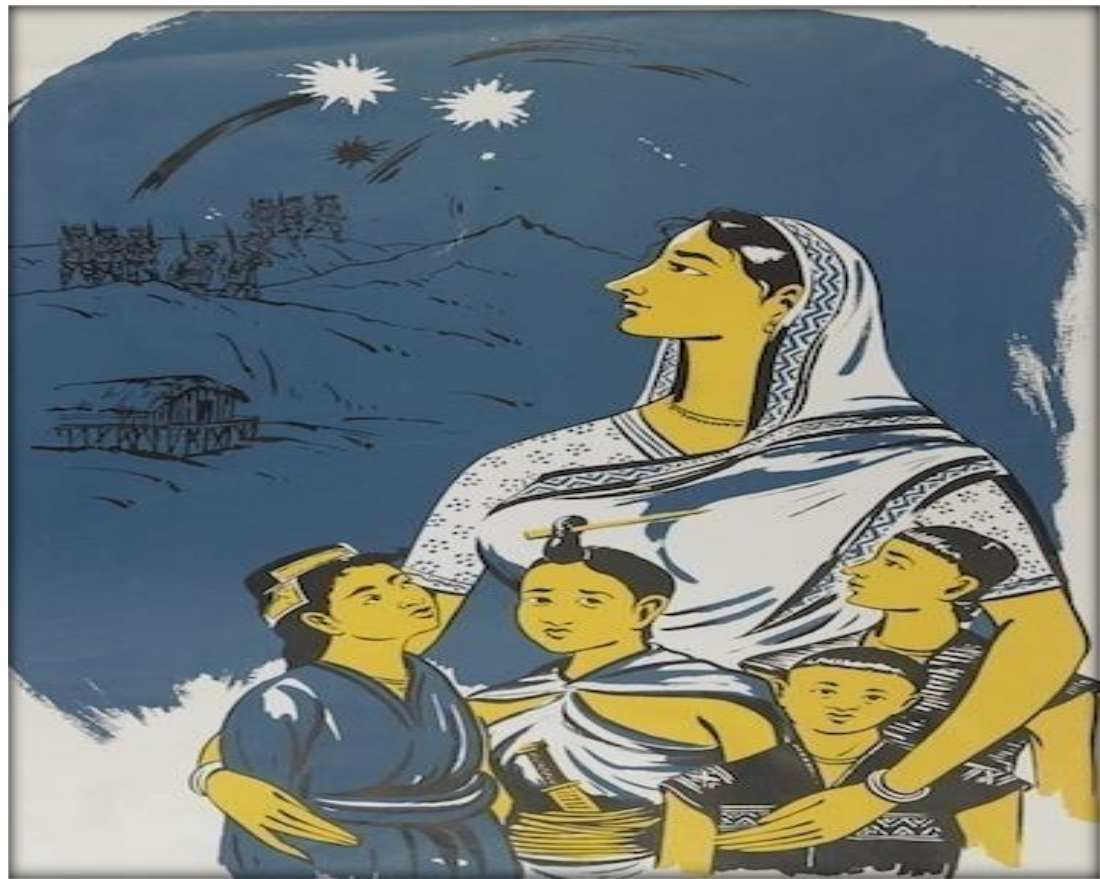

Figure 3

Source: Rechard, 2018 


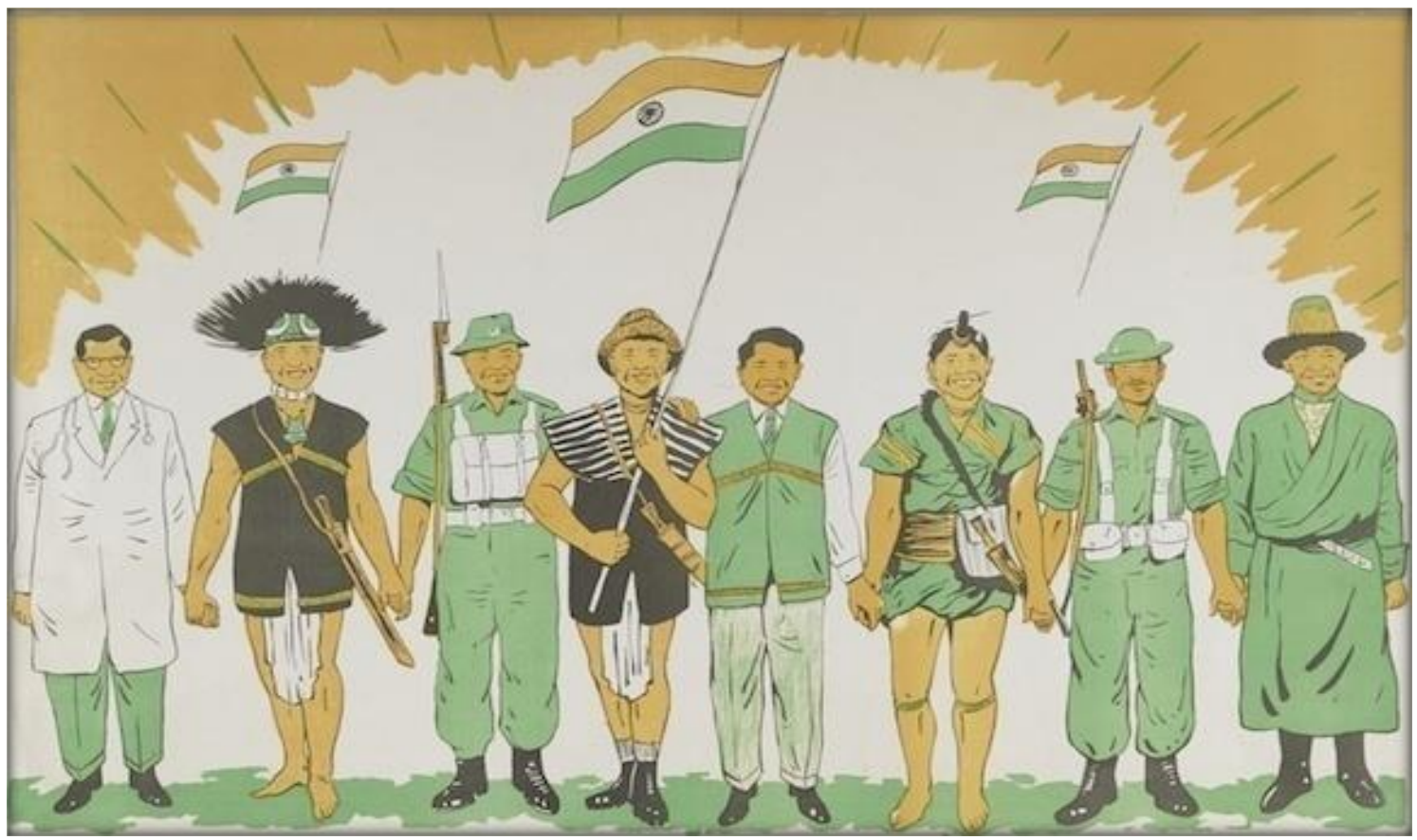

Figure 4

Source: Rechard, 2018

The Figures 1-4 were produced by Indian authorities administering NEFA after the SinoIndian War of 1962 (Rechard, 2018). Individually and collectively, these figures painted in the immediate aftermath of the Sino-Indian War represent the beleaguered Indian authorities' attempts to shape the historical memory of the conflict, and in doing so, to protect their position vis-à-vis Indian public opinion and local Himalayan inhabitants. Each figure encapsulates a scene evoking the war. In Figure 1, five NEFA inhabitants chase away a group of beasts with the body of a bison and the heads of Chinese soldiers. In Figure 2, the Chinese are represented in human form, appearing ominously over the crest of the Himalayas. A group of Indian soldiers(jawans)are ready to repel them, while in the foreground, four inhabitants tend to a wounded soldier. In Figure 3 , the Chinese invaders are still there on the horizon, but this time the focus is on a sari-clad Indian woman, looking anxiously at them while hugging a group of NEFA children close to her. Figure 4 conversely shows no trace of the Chinese, but the war is still there implicitly. Eight men-four NEFA inhabitants and four civilian and military representatives-hold hands, smiling straight ahead while Indian flags flutter over their heads (Rechard, 2018).
What is striking about these figures is that the focus of attention is not on the fighting, nor so much on the enemy, but on the relationship between the inhabitants of NEFA and the Indian state's representatives - a relationship represented as defined by empathy, solidarity and patriotism. These posters provide another striking example of nationalisation effort.

The introduction of Hindi language in NEFA as the medium of instruction was a vital process of exercising nationalist hegemony. $\mathrm{B}$. V. Kesar, the Minister of Information and Broadcasting (19521962), Government of India believed that Hindi would provide 'same kind of cultural link between NEFA and the rest of the country.'(Dawar, 2001:638). The Financial adviser to the Governor of Assam, Shri R.M. Aggarwal stated in a note that it is desirable to have 'a Hindi-speaking NEFA'. A policy document's seventh chapter devoted to the question of language includes the following directions:

It has been now decided that Hindi will become the medium of higher instruction in NEFA and, in time, the lingua franca that will unite not only the diverse populations within its borders but also its people with the people of 
the Plains, who themselves as loyal citizens will naturally be also learning the same language. All our officers, therefore, should not only learn Hindi themselves, but also should encourage its study in every way by the tribal people in their care. (Dawar, 2001:638).

The policy of introducing the Hindi language as the medium of instruction was contested by Assamese public opinion. They were in favour of the introduction of Assamese language on the ground that a broken form of Assamese was for long the accepted lingua franca between the hill people and the plains people. After the war of 1962, particularly at the end of 1965, the position concerningthe medium of instruction worked out as follows: instruction in Assamese began in grade one, Hindi in grade three and English in grade four (Chowdhury 1996:257). When soldiers of the Indian Army and Border Roads Organisation employees entered the area, the indigenous people learnt to converse in Hindi. Gradually, Hindi became the lingua franca of different tribes inhabiting the region (Oinam, 2012).

However, the elderly population of NEFA seem to have not liked the widespread use of Hindi by the young generation. They are concerned that their indigenous language is under threat. The elders of Yagrun village of Pasighat during Solung (an agricultural festival celebrated by the Adi tribe) festival said,

Adi does not have a script. It is an oral language. Young people today do not know how to speak Adi. The children of wealthy people do not study here. They study far away. When they visit, they speak English and Hindi, though they are Adis. If we speak in Adi, we are stupid. If they can speak in English and Hindi, we are stupid. That is what is happening. They forget their own language.(Baruah, 2017)

Another recent development in the state of Arunachal Pradesh is the entry of Sangh Parivar. The presence of Sangh Parivar in the state can be traced back to 1970s (Zavos et al., 2012).
Proselytisation activities of Christian missionaries had created anti-Christian sentiments among the indigenous tribals.Amid communal tensions, the Vivekananda Kendra made its entry in Arunachal Pradesh by setting up six schools in the year 1977. Some key features of the school are the following: admission is only be given to children in the age group of 5-6 years; these are residential schools, giving importance to tradition in curriculumemphasis on "respecting, preserving and nurturing the traditional culture, values and customs of the people of Arunachal Pradesh (Joshy \& Seethi, 2015:52)." During the last three decades, Vivekanda Kendra Vidyalaya (VKV) alumni have come to occupy the top-most positions of bureaucratic and other fields of social service. These former VKVstudents are the torchbearers of Hindu nationalism in the state. The VKV has two major affiliates-ArunJyoti, a cadre-based organisation working in the cultural arena indulged in integrating Hinduism with indigenous tradition. And Vivekananda Kendra Institute of Culture (VKIC) whose fundamental aim is to 'defend' indigenous culture from the influence of 'alien' culture. In this mission, the VKIC has built a strong alliance with the intellectuals of the local communities and coordinates the activities of different indigenous organisations. Arunachal Vikas Parishad (AVP) is an affiliate of the RSS working among the tribal sections (Bertil, 2011). In this way, they are promoting Hindu nationalism.

In addition to infrastructural development and the nationalisation of the border territories, there has been an ardent endeavour towards wild life conservation and maintaining the ecological balance, thereby expecting international support and goodwill. Keeping this in mind, a large number of protected areas have been created along the Sino-Indian border in the last couple of decades. But unfortunately in the protected areas, the indigenous people have lost their rights to the land and forest resources.

In 2004, the Tsangyang Gyatso World Peace Park was set up at Tawang. For this biosphere reserve an area of 2,000 sq. Km (772 sq. Mile) was enclosed. In 1998, the Dihang-Dibang Biosphere 
Reserve was created spreading across an area of 5,112 sq. Km(1973sq. Mile) In 2012, following the rescue of tiger cubs there, the Dibang Tiger Reserve was proposed, with its northern boundary stretching to the international border. An area of 4129 sq. Km of the 9129 sq. KmDibang Valley is designated as Dibang Wildlife Sanctuary but has not been named a Tiger reserve (A Tiger Reserve consists of a 'core' or 'critical tiger habitat which is to be managed as an inviolate area, and a buffer or peripheral area immediately abutting a core area, which may be accorded a lesser degree of habitat protection). The President of Idu Mishmi Cultural and Literary Society who happens to represent the tribes of Dibang valley expressing their fear stated that as the area designated as a sanctuary forms a large part of the Dibang Valley. If the remaining area too is marked as a tiger reserve, it will be at the cost of the people habitats and farmlands (Naqvi, 2018). According to the Mishmis, the sanctuary was created without people's consent, and this has been a point of contestation between the state forest department and the local Mishmi population. The Mishmi Hills is emerging as a new site for conservation with the efforts of conservation NGOs to control traditional hunting practices and resource use. Geographical Information System (GIS), remote sensing technologies, and camera trap technology are being used by scientific experts and state planners to showcase rich biodiversity that often excludes consideration of the human inhabitants in "favour of a focus on dense vegetation cover and biological complexity" (Aiyadurai\& Lee 2017:382).

\section{Conclusion}

The study is an attempt to analyse the socioeconomic consequences of the Sino-Indian war of 1962 on the ethnic communities of NEFA, presently the state of Arunachal Pradesh. From the above discussion, it is apparent that the Sino-Indian war of 1962 is a landmark event in the socio-economic history of Arunachal Pradesh. Before the war, the Government followed a policy of gradual integration of the tribes of North East India with the mainstream of the country. The Himalayas were perceived as an impenetrable natural frontier. When China attacked in the year 1962, the Government of India had realised the strategic importance of frontier regions, including NEFA. Apart from being a frontier region, it was inhabited by tribes who had a racial affinity with the tribes living across the border. Therefore, the Government initiated a significant shift in its policies on NEFA. The Government not only stressed on development of the region, but steps were also taken towards nationalisation of the frontier. Allocation of colossal fund for the development of communication, improvement of medical facilities and education were among the primary development agenda undertaken by the Government. Nationalisation efforts in the field of education are particularly noteworthy. Hindi was introduced as the medium of instruction in schools. From the 1970s, Vivekananda Kendra is undertaking significant steps to initiate Hindu nationalism. The indigenous students educated at VKV schools have become torchbearers of Hindutva in Arunachal Pradesh. The colonisation of nature by setting up national parks and biosphere reserves is another noteworthy initiative taken by the Government of India. While the Government has succeeded in implementing its policies, it has also created tension between the state and the tribes. The indigenous tribes are concerned about losing identity and traditional livelihood in the wave of nationalisation of the frontier. This study, based on ethnocentric perspectives, will serve as a precursor to further in-depth study on the subject.

\section{References}

Aiyadurai, A., \& Lee, C. (2017). Living on the Sino-Indian Border: The Story of Mishmis in Arunachal Pradesh. Asian Ethnology, 76(2), 367-395. DOI: 10.2307/90017668

Barpujari, H. (2007). The Comprehensive History of Assam, Vol 3 (3rd ed., p. 99). Guwahati: Publication Board, Assam.

Baruah, J. (2017). On the Border of India and China, the Adi Face a Confluence of Issues. Retrieved 9 April 2020 from 
https://www.culturalsurvival.org/news/borderindia-and-china-adi-face-confluence-issues

Baruah, S. (2003). Nationalising Space: Cosmetic Federalism and the Politics of Development in Northeast India. Development and Change, 34, 915-39 doi: 10.1111/j.14677660.2003.00334.x

Baruah, S. (1985). A Comprehensive History of Assam (1st ed., pp. 391-395). Munshiram Manoharlal Publishers.

Bertil, D. ,Jaoul, N. \&Kanungo, P. (2011). Cultural Entrenchment of Hindutva: Local Mediations and Forms of Convergence (pp. 10317). Routledge India

Bhattacharjya, R. (1991). Working of Constitutional Reforms in Assam 1906-1946 (PhD). Gauhati University.

Burkitt, L., Scobell, A., \&Wortzel, L. (2003). The Lessons of History: The Chinese People's Liberation Army at 75 (1st ed., p. 343). American Enterprise Institute.

Chowdhury, J. (1996). Arunachal Panorama: A Study in Profile (p. 249-260). Itanagar:

Directorate of Research.

Cultural Roots of Arunachal Pradesh. (2019). Retrieved 7 May 2020, from https://blog.mygov.in/cultural-roots-ofarunachal-pradesh/

Dalvi, J. P. (1969). Himalayan Blunder (pp. 127128). Bombay: Thacker \& Company Limited.

Dawar, J. (2001) Contending Hegemonies in Arunachal Pradesh Since 1950s: Language, Script and Tribal Cultural identity among the Adi, Proceedings of Indian History Congress, 62, 637-648 DOI: 10.2307/44144162

Elwin, V. (1959). A Philosophy for NEFA (2nd ed., pp. 8-13). Shillong: North-East Frontier Agency.

Guyot-Réchard, B. (2017). Shadow States: India, China and the Himalayas,1910-1962 (1st ed.). Cambridge University Press.

Hindustan Standard. (1963). Chinese Resisted by Villagers:Story of Courage and Patriotism, $p$. 4.
History. (2020). Retrieved 12 March 2020, from https://itanagar.nic.in/history/

Hussain, M. (1998). Encyclopaedia of NorthEast India, Vol 1 (1st ed., pp. 11-31). New Delhi: Rima Publishing House.

India, G. (2006). Official History of the 1962 India China War - Bharat Rakshak - Indian Army \& Land Forces. Retrieved 6 May 2020, from https://bharatrakshak.com/ARMY/history/1962war/266official-history.html

Joshy, P., \& Seethi, K. (2015). State and Civil Society under Siege: Hindutva, Security and Militarism in India (1st ed., p. 52). Sage Publications India.

Kumar, B. (2013). Unknown and Unsung: Indian Air Force in Sino-Indian War of 1962 (1st ed., pp. 6-11). KW Publishers.

Lintner, B. (2018). China's India War: Collision Course on the Roof of the World (1st ed.). Oxford University Press.

Maxwell, N. (1970). India's China war (2nd ed., pp. 40-56). Jaico Pub. House.

Naqvi, S. (2018). Arunachal Tribe against Tiger Reserve. Hindustan Times. Retrieved 26 April 2020, from https://www.hindustantimes.com/indianews/arunachal-tribe-against-tigerreserve/story-40UTJv4W8Y3cu1713faA3L.html.

Oinam, S. (2012). India Lost War with China but Won Arunachal's Heart. Retrieved 14July 2018, from

https://timesofindia.indiatimes.com/india/Indi a-lost-war-with-China-but-won-Arunachalsheart/articleshow/17039530.cms

Pande, B. (1997). Arunachal Pradesh: Village State to Statehood (p. 8). Itanagar: Himalayan.

Rechard, B. (2018). Coping with Defeat: Indian Posters of the 1962 Sino-Indian War. Retrieved 13 April 2020, from https://histecon.fas.harvard.edu/invisiblehistories/captions/defeat/index.html

Sadatulla, M. (2013). 1962 War: Supplying from the Air (1st ed.). KW Publishers. 
Sharma, M. (2008). Economy of Arunachal Pradesh: Problems, Performance and Prospects (p. 20). Guwahati: DVS Publishers.

Sharma, P. (1988). Architecture of Assam (p. 205). Delhi: Agam Kala Prakashan.

Singh, M. (2011). Arunachal Pradesh:

Wonderland with Explosive Frontier. The Indian Journal of Political Science, 72(1), 205.

Retrieved from, https://www.jstor.org/stable/42748418?seq=1 DOI: $10.2307 / 42748418$

Verma, S. (2016). 1962: The War That Wasn't (1st ed.). Aleph Book Company.

Zavos, J., Kanungo, P., Reddy, D., Warrier, M., \& Williams, R. (2012). Public Hinduisms (1st ed., p. 90). Sage Publications India.

\section{Conflict of Interest}

There is no conflict of interest

\section{Acknowledgements}

We would like to express our gratitude to the anonymous reviewers whose insights have helped in improving the paper. We also owe thanks to the journal for accepting the paper.

\section{Author Contribution}

While Syeda Fauzia Farmin, who is a PhD scholar, has written the paper, Dr Barnali Sarma supervised the work, provided the idea and contributed in writing and reviewing the paper.

\section{Declaration}

We declare that the figures used in the research paper are collected from the State Archives of Arunachal Pradesh and British library by the original author, Dr. Berenice Guyot-Rechard, Senior Lecturer of King's College, London. We have contacted Dr. Berenice for permission. As we have drawn on the ideas put forward by the author in the article, she has asked us to cite and refer readers to the website. 